\title{
The role of obesity and adipose tissue dysfunction in gestational diabetes mellitus
}

\author{
Patrik Šimják1, Anna Cinkajzlová2,3, Kateřina Anderlová1,4, Antonín Pařízek1, Miloš Mráz²,5, Michal Kršek,6 and \\ Martin Haluzík 2,3,5 \\ 1Department of Gynaecology and Obstetrics, First Faculty of Medicine, Charles University and General University Hospital, Prague, Czech Republic \\ 2Institute of Medical Biochemistry and Laboratory Diagnostics, First Faculty of Medicine, Charles University and General University Hospital, Prague, \\ Czech Republic \\ ${ }^{3}$ Centre for Experimental Medicine, Institute for Clinical and Experimental Medicine, Prague, Czech Republic \\ 43rd Department of Medicine, First Faculty of Medicine, Charles University and General University Hospital, Prague, Czech Republic \\ ${ }^{5}$ Diabetes Centre, Institute for Clinical and Experimental Medicine, Prague, Czech Republic \\ ${ }^{6}$ nnd Internal Department, 3rd Faculty of Medicine, Charles University and University Hospital Královské Vinohrady, Prague, Czech Republic
}

Correspondence should be addressed to M Haluzík: halm@ikem.cz

\section{Abstract}

Gestational diabetes mellitus is defined as diabetes diagnosed in the second or third trimester of pregnancy in patients with no history of diabetes prior to gestation. It is the most common complication of pregnancy. The underlying pathophysiology shares some common features with type 2 diabetes mellitus (T2DM) combining relatively insufficient insulin secretion with increased peripheral insulin resistance. While a certain degree of insulin resistance is the physiological characteristics of the second half of pregnancy, it is significantly more pronounced in patients with gestational diabetes. Adipose tissue dysfunction and subclinical inflammation in obesity are well-described causes of increased insulin resistance in non-pregnant subjects and are often observed in individuals with T2DM. Emerging evidence of altered adipokine expression and local inflammation in adipose tissue in patients with gestational diabetes suggests an important involvement of adipose tissue in its etiopathogenesis. This review aims to summarize current knowledge of adipose tissue dysfunction and its role in the development of gestational diabetes. We specifically focus on the significance of alterations of adipokines and immunocompetent cells number and phenotype in fat. Detailed understanding of the role of adipose tissue in gestational diabetes may provide new insights into its pathophysiology and open new possibilities of its prevention and treatment.

Key Words
- obesity
- adipose tissue
gestational diabetes
mellitus
- inflammation
- adipokines

Journal of Endocrinology (2018) 238, R63-R77

\section{Introduction}

Gestational diabetes mellitus (GDM) is the most common metabolic disorder of pregnancy. It is defined as diabetes diagnosed in the second or third trimester of pregnancy in patients with no history of diabetes prior to gestation (ADA 2017). The prevalence of GDM is increasing rapidly worldwide along with the changes in lifestyle, growing incidence of obesity and older age of pregnant women.
It complicates 4-20\% pregnancies depending on screening method used, gestational age and the population studied (Hollander et al. 2007). Numerous risk factors for GDM development were described. The most important ones include family history of type 2 diabetes mellitus (T2DM) or GDM, especially in the first-degree relatives, previous history of GDM or macrosomic newborn, advanced 
maternal age and obesity (Di Cianni et al. 2003). GDM is associated with an increased risk of pregnancy complications for both mother and child, including among others cesarean delivery, shoulder dystocia, macrosomia and neonatal hypoglycemia (Metzger et al. 2008). Fetal hyperinsulinism due to maternal hyperglycemia results in exaggerated fetal anabolism, growth of the fetal adipose, bone and muscle tissue and subsequent macrosomia. The newborns are prone to neonatal hypoglycemia, hyperbilirubinemia, hypocalcemia, respiratory distress syndrome and polycythemia (Hod et al. 1991).

In the long term, epigenetic changes induced by in utero exposure to maternal hyperglycemia increase the risk of obesity (Desai et al. 2013), T2DM (Clausen et al. 2009), cardiovascular diseases (Wu et al. 2012) and neuropsychiatric morbidity (Nahum Sacks et al. 2016). Although the underlying pathogenic mechanism is still unknown, epigenetic changes during fetal life are implicated.

In addition, women with GDM are more than seven times more likely to develop T2DM and approximately 50\% of mothers with GDM will develop T2DM within 10 years (Bellamy et al. 2009). This makes GDM one of the strongest predictors of T2DM. The risk of developing cardiovascular morbidity later in life is also substantially increased (Sullivan et al. 2012). Risk factors and consequences of GDM are summarized in Fig. 1. During pregnancy, significant changes in maternal glucose metabolism occur. Insulin sensitivity typically decreases in the late gestation (Catalano et al. 1991). There is a significant increase in basal hepatic glucose production by the third trimester of pregnancy accompanied by a significant increase in basal insulin secretion (Catalano et al. 1992). These changes take place on the background of pregestational metabolic status. The underlying pathophysiology of GDM lies in an inability of pancreatic beta-cells to maintain adequate insulin response to increased peripheral insulin resistance. Physiological insulin resistance in the second half of pregnancy thus creates an increased challenge to beta-cells' functional reserve that may unmask inherited or acquired predisposition to impaired glucose metabolism. Increasing evidence from clinical and experimental studies indicates that metabolic and endocrine dysfunction of adipose tissue plays an important role in the pathophysiology of GDM.

\section{Obesity and pregnancy}

Obesity is increasing in prevalence worldwide, and it is associated with adverse short- and long-term health outcomes for the mother and the offspring (Leddy et al. 2008, Tenenbaum-Gavish \& Hod 2013). It is estimated, that up to $50 \%$ of women of reproductive age are either overweight ( BMI $25-29.9 \mathrm{~kg} / \mathrm{m}^{2}$ ) or obese (BMI $>30 \mathrm{~kg} / \mathrm{m}^{2}$ ) (Kanagalingam et al. 2005). The prevalence of maternal obesity at the beginning of pregnancy is increasing and currently exceeds $16 \%$ (Heslehurst et al. 2007). Also, the prevalence of childhood obesity rises steadily. In the United States, 8.9\% among 2- to 5-year-old children and $17.5 \%$ among 6- to 11-year-old children are obese (Ogden et al. 2015).

Both prepregnancy obesity and excessive gestational weight gain have been associated with higher risk of adverse pregnancy outcomes, such as macrosomia, GDM, preeclampsia and cesarean delivery (Li et al. 2013, Liu et al . 2015). The offspring of obese mothers have a higher risk of congenital anomalies and tend to be large for gestational age at birth (Stothard et al. 2009, Gaudet et al. 2014). Children of obese women, particularly those, who are born large for gestational age, are prone to development of obesity, metabolic syndrome and subsequent increase in cardiovascular morbidity (Whitaker 2004, Drake \& Reynolds 2010). Similar to GDM, obese women are also at increased risk of metabolic and cardiovascular disorders later in life (Lavie et al. 2009, Pi-Sunyer 2009).

Obesity and GDM are frequently comorbid conditions. The risk of developing GDM is increased three-fold in obese women compared to women with normal BMI (Leddy et al. 2008). When coinciding with GDM, obesity and excessive gestational weight gain increase the risk of numerous GDM complications (Berggren et al. 2015, Xiong et al. 2016). Children of obese women with GDM are more likely to develop obesity and insulin resistance, which can lead to a vicious cycle of metabolic disorders into the next generation. Maternal obesity is an important predictive factor for the development of obesity, cardiovascular disease and T2DM in the offspring (Dabelea et al. 2008, Gaillard et al. 2014).

\section{Mechanisms of obesity-induced insulin resistance and disturbed glucose metabolism in pregnancy}

Adipose tissue serves not only as the lipid storage depot but is also an active endocrine organ secreting factors that can both improve and impair insulin sensitivity. While subcutaneous adipose tissue accumulation manifesting by gynoid type of obesity does not represent a major metabolic risk, accumulation of visceral adipose tissue in 


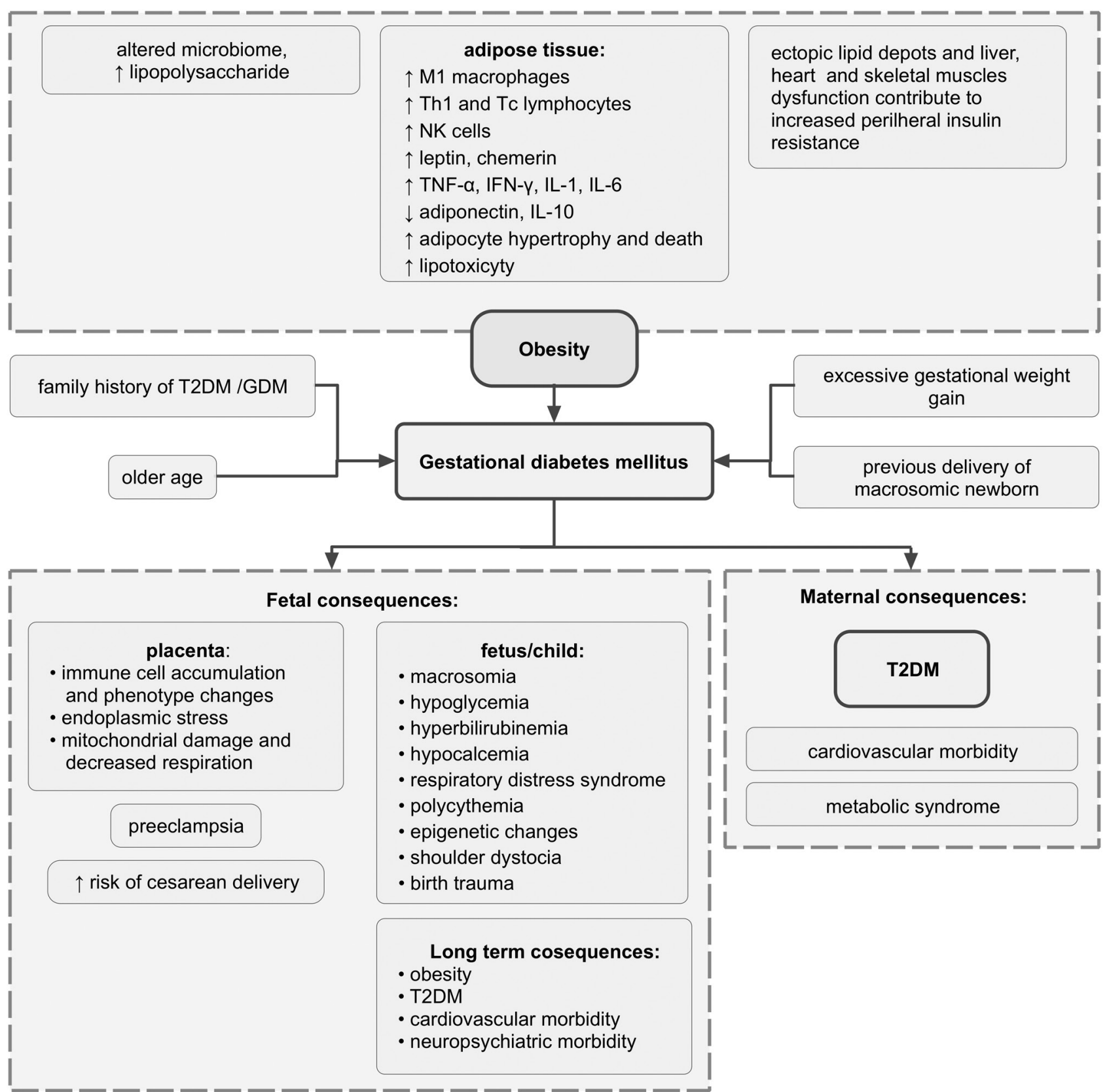

\section{Figure 1}

GDM: risk factors and consequences. GDM is associated with an increased risk of pregnancy complications and future metabolic complications for the mother and the offspring. Obesity is one of the major risk factors of gestational diabetes. Prepregnancy obesity is related to the subclinical inflammation in adipose tissue and alteration of the intestinal microbiome. GDM, gestational diabetes mellitus; IFN- $\gamma$, interferon gamma; IL, interleukin; NK cells, natural killer cells; T2DM, type 2 diabetes mellitus; Tc lymphocytes, T cytotoxic lymphocytes; Th lymphocytes, T helper lymphocytes.

the abdominal region is associated with a greater risk of insulin resistance, cardiovascular diseases, hypertension and T2DM (Samsell et al. 2014). Lipid storage capacity of adipose tissue is limited. Once it is exceeded, ectopic lipids are excessively deposited in liver, heart and skeletal muscles, leading to impairment of insulin signaling cascade and impaired glucose uptake (Unger 2003).
Adipose tissue dysfunction eventually leads to local subclinical inflammation that further impairs insulin signaling and increases cardiovascular risk (Boren et al. 2013). Adipose tissue dysfunction primarily occurring in visceral adipose tissue is linked to obesity and metabolic syndrome development, and it is a promising subject of research with a potential for treatment of these pathologies 
(Bluher 2009). As described in detail below, obesity and T2DM are accompanied by numerous changes in adipose tissue endocrine function and local inflammation. Some of these changes seem to accompany GDM as well (Al-Badri et al. 2015). Understanding the role of adipose tissue in GDM, thus, may provide new insights into its pathophysiology, potentially opening new possibilities for its treatment in the future.

\section{Adipokines and GDM}

Numerous human studies established that obesity is associated with alterations of adipose tissue composition and expression profile. The first change characterizing obesity is adipocyte hypertrophy (Jo et al. 2009). Persistent adipocyte hypertrophy is connected with adipocyte dysfunction, altered adipocyte expression profile and lipid metabolism resulting in local lipotoxicity, local hypoxia, dysregulation of adipokine production and adipocyte death (Winkler et al. 2003, Jernas et al. 2006, Hosogai et al. 2007, Halberg et al. 2008, Veilleux et al. 2011). These changes constitute a stimulus for the infiltration of adipose tissue by immune cells, the development of subclinical inflammation and insulin resistance (Cinti et al. 2005). Similar to T2DM, the changes of adipokine and cytokine production were also detected during GDM development and progression (Lopez-Tinoco et al. 2012).

The healthy adipose tissue of the lean subjects is a primary source of adiponectin. Adiponectin has several positive properties such as stimulation of antiinflammatory interleukin (IL)-10 and suppression of proinflammatory interferon gamma (IFN- $\gamma$ ) production (Wolf et al. 2004). It also improves hepatic insulin sensitivity (Ward et al. 2001), reduces TNF- $\alpha$-stimulated expression of cell adhesion molecules (Ouchi et al. 1999) and inhibits lipopolysaccharide inflammatory actions (Ajuwon \& Spurlock 2005). While it does not appear to be affected by sex hormones changes during menstrual cycle (Kleiblova et al. 2006), it is markedly lowered in obesity (Haluzik 2005). Similar to obese subjects (Haluzik et al. 2004), normal-weight women with GDM have decreased adiponectin levels (Ranheim et al. 2004), and hypoadiponectinemia could be considered as a predictive marker of GDM development in early pregnancy (Bao et al. 2015, Iliodromiti et al. 2016). Macrosomia of newborns is also connected with decreased adiponectin, and maternal adiponectin levels are inversely associated with neonatal birth body weight (Sylven 1993, Arora et al. 2003). Interestingly, adiponectin supplementation restored maternal insulin sensitivity, placental insulin/ mTORC1 and peroxisome proliferator-activated receptor alpha signaling, nutrient transport and fetal growth in obese GDM C57BL/6J mice (Aye et al. 2015). Women with a history of GDM have lower adiponectin levels even after adjustment for insulin sensitivity or the degree of obesity (Winzer et al. 2004). Lower adiponectin concentrations are associated with subclinical inflammation, atherogenesis (Winzer et al. 2004) and independently predict future dyslipidemia (Lekva et al. 2017). Moreover, high leptin/ adiponectin ratio in pregnancy and in particular in patients with GDM is linked to an unfavorable cardiovascular risk profile during follow-up (Lekva et al. 2017). Apart from adipose tissue, another potential source of adiponectin is the placenta (Kleiblova et al. 2010). Placental adiponectin secretion could be negatively modulated by TNF- $\alpha$, IFN- $\gamma$, IL-6 and leptin (Chen et al. 2006), but the impact of GDM is unclear due to contradictory data (Chen et al. 2006, Mrizak et al. 2014).

In opposite to adiponectin, leptin is increased in obese subjects and women with GDM (Kautzky-Willer et al. 2001, Krizova et al. 2004, Anderlova et al. 2006). Early hyperleptinemia is a predictor of GDM risk (Qiu et al. 2004), and it precedes the changes in maternal glycemia (Gao et al. 2008). Interestingly, mice lacking the suppressor of cytokine signaling 3 gene (Socs3) in cells expressing leptin receptors have most of the obesity-induced metabolic changes diminished, resulting in the prevention of leptin and insulin resistance without affecting the ability to carry their gestation to term (Zampieri et al. 2015). In general, leptin reduces food intake and increases energy expenditure (Halaas et al. 1995) and in contrast to adiponectin, it has rather proinflammatory actions. It can contribute to macrophage recruitment (Gruen et al. 2007) along with increased immune cell activation and differentiation (Lord et al. 1998, Papathanassoglou et al. 2006, Claycombe et al. 2008). Leptin levels are partially dependent on ethnicity mirroring higher GDM risk in South Asians compared to Europeans (Sommer et al. 2015). Maternal glycemia inversely correlates with methylation rate of the human $L E P$ locus, and these epigenetic changes could be associated with future obesity development in the child (Allard et al. 2015). Both fetal leptin and leptin produced by placental vascular endothelial cells increase with maternal body weight (Tsai et al. 2015a). Leptin is released in a greater amounts from placental tissues compared to amnion and chorion, and basal leptin release is decreased from these tissues and increased from adipose tissue and skeletal muscle in GDM compared to healthy pregnant women (Lappas et al. 2005). This is more 
pronounced in GDM women treated by insulin than GDM women treated by diet (Lappas et al. 2005).

Besides classical adipokines including adiponectin and leptin, several other adipokines were examined in the context of GDM. One of these adipokines is chemerin, which is involved in the regulation of adipocyte development and liver, skeletal muscle and adipose tissue metabolism (Goralski et al. 2007, Yang et al. 2010). Chemerin is produced by the adipose tissue with significantly higher chemerin mRNA expression found in subcutaneous compared to visceral adipose tissue and in obese compared to lean subjects (Alfadda et al. 2012). Circulatory chemerin levels are increased in obesity and T2DM (El-Mesallamy et al. 2011), and there is a significant negative correlation between circulating chemerin levels and chemerin mRNA expression in subcutaneous adipose tissue (Alfadda et al. 2012). Data in GDM patients are contradictory (Pfau et al. 2010, Hare et al. 2014, Fatima et al. 2017), most probably owing to different diagnostic criteria of GDM and variable sample size and mean BMI of the trial cohorts used. The study comprising the largest sample size reported a sevenfold increase in plasma chemerin levels in women with GDM compared with healthy pregnant controls in the third trimester of pregnancy (Fatima et al. 2017). In this study, IADPSG criteria for the diagnosis of GDM were applied. In another study, normoglycemic obese women had higher chemerin levels compared to normal-weight normoglycemic women, and GDM normal-weight women had higher chemerin levels compared to obese GDM women (Li et al. 2015). Arterial cord blood chemerin levels were increased with GDM and venous chemerin cord blood levels were higher in children of obese women, and both arterial and venous chemerin levels positively correlated with maternal chemerin at birth (van Poppel et al. 2014). Chemerin levels were suggested as a marker of preeclampsia severity and high maternal chemerin is related to adverse neonatal outcomes (Cetin et al. 2017). In general, chemerin is associated with obesity, inflammation and insulin resistance (Sell et al. 2009) and regulates adipocyte development and metabolic functions (Goralski et al. 2007). Moreover, chemerin could have some positive functions due to its protective effect on regulation of nitric oxide signaling. Chemerin inversely correlates with serum nitric oxide synthase levels and increases nitric oxide synthase and protein kinase B levels, decreases TNF- $\alpha$ signaling and vascular cell adhesion molecule 1 expression in human umbilical vein endothelial cells (Wang et al. 2015).
Another adipokine, visfatin, was originally considered potentially protective against insulin resistance but its ability to directly bind to the insulin receptor and activate insulin signaling pathway was not confirmed (the original article was hereafter retracted by the authors (Fukuhara et al. 2005)). Nevertheless, it has been shown that visfatin is actively produced by macrophages (Svoboda et al. 2017), enhances cytokine production in leukocytes and induces leukocyte chemotaxis (Moschen et al. 2007). Increased plasma visfatin concentrations were described in overweight/obesity, T2DM and metabolic syndrome (Chang et al. 2011). However, the results in GDM are unambiguous. Increased (Krzyzanowska et al. 2006, Lewandowski et al. 2007) as well as decreased (Chan et al. 2006, Haider et al. 2007) visfatin levels were described. In addition, no difference in visfatin mRNA expression in subcutaneous adipose tissue, visceral adipose tissue and placenta was observed between GDM and normoglycemic women (Telejko et al. 2009). The significance of visfatin in GDM is poorly understood. According to ex vivo human and rat studies, visfatin inhibits myometrial contractility even more potently than leptin (Mumtaz et al. 2015). Visfatin is also significantly associated with placental sirtuin 1 levels. Sirtuin 1 is a nuclear protein that regulates cell survival, cellular senescence, differentiation, metabolism and inflammation in numerous tissues such as liver, muscle, pancreas, testis, ovary and adipose tissue via heterochromatin formation by deacetylation of histones and non-histone proteins including transcription factors (Shoba et al. 2009, Chung et al. 2010). Increased visfatin levels potentially prevent a labor-associated decrease of sirtuin 1 leading to post-term delivery in obese women (Tsai et al. 2015b). Omentin is an adipokine with insulinsensitizing action, which is secreted by visceral adipose tissue and decreased in patients with obesity (de Souza Batista et al. 2007). Maternal obesity is characterized by decreased omentin-1 levels in maternal circulation, and its levels are lower in non-obese GDM compared to nonobese normoglycemic women (Barker et al. 2012). On the contrary, there is no difference between obese GDM and obese normoglycemic women suggesting a role of both GDM and obesity in modulation of omentin levels. Maternal obesity does not affect umbilical cord omentin levels, and placental and adipose tissue omentin-1 expression is not influenced by GDM (Barker et al. 2012). Maternal omentin-1 levels inversely correlate with fetal birth weight and fetal ponderal index (Barker et al. 2012).

Resistin is an adipokine named after its ability to induce insulin resistance in mice (Steppan et al. 2001). 
In obese humans, resistin is increased and positively correlated with increased adiposity and inflammation (Vozarova de Courten et al. 2004, Piestrzeniewicz et al. 2008). Resistin promotes monocyte-endothelial cell adhesion (Manduteanu et al. 2010, Hsu et al. 2011), induces TNF- $\alpha$ and IL-12 expression in macrophages (Silswal et al. 2005) and acts as a modulator of macrophagefoam cell transformation ( $\mathrm{Xu}$ et al. 2006). The results of studies exploring resistin levels in GDM patients are inconsistent. Increased (Chen et al. 2007, Kuzmicki et al. 2009), unchanged (Lappas et al. 2005) and lowered (Megia et al. 2008) resistin levels were described in GDM women compared to healthy pregnant women. Moreover, some studies found no correlation between resistin levels and preeclampsia incidence or maternal BMI (Hendler et al. 2005). Resistin levels in newborns of GDM mothers did not differ from newborns of normoglycemic mothers ( $\mathrm{Ng}$ et al. 2004). Furthermore, there were no differences in resistin release from human placenta and fetal membranes, neither between subcutaneous adipose tissue nor skeletal muscle obtained from healthy pregnant women and those with GDM (Lappas et al. 2005).

Vaspin or visceral adipose tissue-derived serpin (serpin A12) is an adipokine secreted predominantly by visceral adipose tissue. Higher levels of vaspin were found in T2DM and obese subjects (Feng et al. 2014). Vaspin levels are associated with circulating leptin, insulin and C-peptide levels and with an amelioration of insulin sensitivity (Handisurya et al. 2010). In GDM women, unchanged (Stepan et al. 2010, Gkiomisi et al. 2013), decreased (Huo et al. 2015) and increased (Mm et al. 2014, Jia et al. 2015) vaspin circulating levels were found. Placental mRNA and protein vaspin levels in the GDM group did not differ from pregnant women with normal glucose tolerance and were inversely correlated to neonatal birth weight in the GDM women (Huo et al. 2015). Adipose tissue vaspin mRNA and protein levels are increased in GDM women (Mm et al. 2014).

Several new adipokines and factors originating from adipose tissue were described in relation with GDM. One of these factors is fetuin A, also known as $\alpha 2$-HeremansSchmid glycoprotein, which is secreted by the liver and adipose tissue (Jialal et al. 2015) and associates with insulin resistance and fat accumulation in the liver (Stefan et al. 2006). Besides that, fetuin A contributes to proinflammatory macrophage phenotype (Chatterjee et al. 2013). Fetuin A is increased during pregnancy and decreases after delivery (Iyidir et al. 2015), and women with GDM have higher fetuin A levels compared to healthy pregnant women suggesting its possible role in metabolic complications accompanying GDM (Kalabay et al. 2002). Furthermore, the dynamics of plasma fetuin $A$ concentrations during pregnancy was altered in patients who develop preeclampsia compared to healthy pregnant women, and it was significantly lower in women with preterm preeclampsia at the time of clinical diagnosis (Chaemsaithong et al. 2014). Similarly, adipokine/ hepatokine fetuin B is increased in GDM women (Kralisch et al. 2017). Increased fetuin B levels were also found in patients with liver steatosis and T2DM. Its administration impaired insulin signaling in muscle and liver in mice (Meex et al. 2015).

Changes in adipokine levels in patients with GDM and obesity, respectively, are summarized in Table 1.

\section{Subclinical inflammation and GDM}

Several mechanisms such as local hypoxia, increased adipocyte death and production of proinflammatory cytokines represent potent stimuli for migration of immune cells into adipose tissue (Sun et al. 2011). In obese subjects, macrophages and lymphocytes appear to be the most important players in the development of subclinical inflammation (Mraz \& Haluzik 2014, Cinkajzlova et al. 2017). Macrophages have in general two main polarization states. In lean subjects, M2 or alternatively activated macrophages that have homeostatic functions and contribute to angiogenesis, wound healing and anti-inflammatory IL-10 production are abundant in adipose tissue. In contrast, M1 or classically activated macrophages connected with proinflammatory actions and TNF- $\alpha$ production occur more often in obese subjects (Sica \& Mantovani 2012). Nevertheless, both polarization states represent the extremes and more often macrophages with mixed phenotype and mixed cytokine production participate in the progression of subclinical inflammation in adipose tissue (Zeyda et al. 2007). Similarly, T lymphocytes have various activation states with anti-inflammatory or proinflammatory functions. In lean subjects, $\mathrm{T}$ helper (Th) 2 and $\mathrm{T}$ regulatory (Treg) lymphocytes producing IL-10, IL-4, IL-13 and IL-5 with anti-inflammatory actions predominate. In contrast, Th1 and Th17 lymphocytes together with $\mathrm{T}$ cytotoxic (Tc) lymphocytes, natural killer (NK) cells providing IFN- $\gamma$ production, proinflammatory actions and cytotoxicity and probably B lymphocytes producing immunoglobulins are more frequently seen in obese subjects (Mills et al. 2000, Kang et al. 2008, Nishimura et al. 2009, McDonnell et al. 2012, Joller et al. 2014, Madhumitha et al. 2014, 
Table 1 Changes in circulating levels of adipokines in patients with gestational diabetes mellitus and obesity (without gestational diabetes).

\begin{tabular}{|c|c|}
\hline Adipokine & Gestational diabetes mellitus \\
\hline Adiponectin & $\downarrow$ (Ranheim et al. 2004) \\
\hline Leptin & $\uparrow($ Kautzky-Willer et al. 2001) \\
\hline \multirow[t]{3}{*}{ Chemerin } & $\uparrow$ (Fatima et al. 2017) \\
\hline & $\downarrow$ (Hare et al. 2014) \\
\hline & No change (Pfau et al. 2010) \\
\hline \multirow[t]{2}{*}{ Visfatin } & $\begin{array}{l}\uparrow(\text { Krzyzanowska et al. 2006, Lewandowski et al. } \\
2007)\end{array}$ \\
\hline & $\downarrow$ (Chan et al. 2006, Haider et al. 2007) \\
\hline Omentin & $\downarrow$ In non-obese (Barker et al. 2012) \\
\hline \multirow{3}{*}{ Resistin } & $\uparrow($ Chen et al. 2007, Kuzmicki et al. 2009) \\
\hline & $\downarrow$ (Megia et al. 2008) \\
\hline & Unchanged (Lappas et al. 2005) \\
\hline \multirow[t]{3}{*}{ Vaspin } & $\uparrow(\mathrm{Mm}$ et al. 2014, Jia et al. 2015) \\
\hline & $\downarrow$ (Huo et al. 2015) \\
\hline & No change (Stepan et al. 2010, Gkiomisi et al. 2013) \\
\hline Fetuin A & $\uparrow($ Kalabay et al. 2002) \\
\hline Fetuin B & $\uparrow($ Kralisch et al. 2017) \\
\hline
\end{tabular}

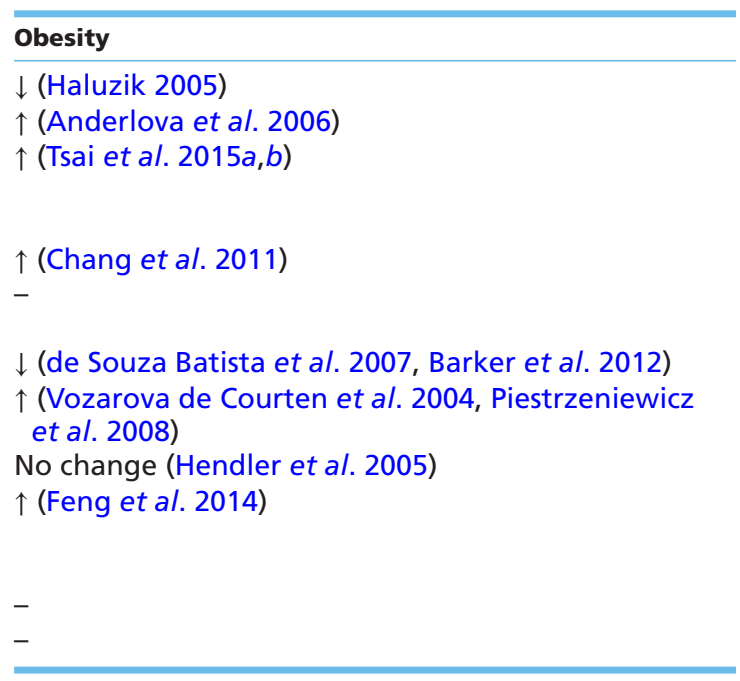

Lee et al. 2016). Natural killer T (NKT) cells have antiinflammatory as well as proinflammatory functions dependent on their antigen structure. With respect to adipose tissue, invariant NKT cell expressing CD1d lipidrecognizing antigen and anti-inflammatory actions are mostly described in the context of obesity (Borg et al. 2007, Schipper et al. 2012).

Immune cells communication is mediated by several routes including production of signaling molecules, selfantigen presentation or by direct cell contacts (Koenen et al. 2011, Chatzigeorgiou et al. 2013, Wensveen et al. 2015, Morris et al. 2016). Increased cytokine levels, in particular TNF- $\alpha$ and IFN- $\gamma$ together with IL-1 or IL-6 along with altered adipokine secretion is one of the major reasons for development of subclinical inflammation in adipose tissue as well as on systemic level. Potentially, obesity during pregnancy could be partially responsible for development of pregnancy complications and indirectly contribute to fetal metabolic status.

Importantly, apart from the significance of immune cell accumulation in adipose tissue, their accumulation in placenta very likely plays a role in GDM development in obese pregnant women. Synergic actions of adipose tissue and placenta were demonstrated in a study aimed at the determination of alternatively activated macrophage marker CD163 secretion. Its soluble form sCD163 was suggested as a prognostic marker of lowgrade inflammation and T2DM. GDM women and their offspring had elevated sCD163 levels compared to controls, together with increased sCD163 protein concentration and greater amounts of CD163-positive cells in the placenta and adipose tissue (Bari et al. 2014).
The placenta contains its own macrophages called Hofbauer cells, which have M2 anti-inflammatory phenotype and protect fetus against pathogen transmission from the mother. However, under proper stimulation, including stimulation by lipopolysaccharide, these cells produce proinflammatory cytokines such as IL-6 and IL-8 (Young et al. 2015). This could have important implications as increased lipopolysaccharide levels were reported in obese subjects (Troseid et al. 2013) and alterations in placental microbiome were described in women with GDM (Bassols et al. 2016). Moreover, higher placental macrophage accumulation, as well as increased placental and macrophage cytokine production, were observed in obese compared to lean pregnant women. Increased placental expression of TNF- $\alpha$, IL- 6 and IL-1 together with increased systemic levels found in women with GDM or preeclampsia suggest a potential placental contribution to systemic inflammation, GDM development and progression (Rinehart et al. 1999, Challier et al. 2008, Yu et al. 2013). Certain roles in macrophage accumulation and inflammatory reactions could be attributed to the proinflammatory cytokine called macrophage migration inhibitory factor, which has pleiotropic immune functions (Nishihira 2000). Migration inhibitory factor concentrations are increased in GDM and its polymorphisms associate with susceptibility to GDM development in pregnancy (Aslani et al. 2011, Yilmaz et al. 2012). Apart from proinflammatory cytokine production, M1 macrophages represent the potential source of reactive oxide species and nitric oxide (Mantovani et al. 2004) that may eventually contribute to the development of adipose tissue (Jang et al. 2016) and placental fibrosis 
(Pustovrh et al. 2000) via mitochondrial dysfunction of preadipocytes and activation of metalloproteinase 9, respectively.

Except for macrophages, lymphocyte populations are also altered during pregnancy and GDM development. According to first murine studies (Dudley et al. 1993, Wegmann et al. 1993), healthy pregnancy is accompanied by anti-inflammatory Th2 lymphocyte response characterized by anti-inflammatory IL-10, IL-4, IL-13 and IL-5 cytokine production, while proinflammatory Th1 lymphocyte response is downregulated. In humans, a limited number of studies are available. Increased percentage of total lymphocytes and CD8 lymphocytes expressing gamma/delta $\mathrm{T}$ receptor have been described in GDM patients along with higher CD8 lymphocytes expressing gamma/delta $\mathrm{T}$ receptor and decreased NK cells in circulation in their newborns. Interestingly, percentage of Th (CD4+) cells in circulation was lower in GDM treated by insulin compared to those treated only by diet (Lapolla et al. 2005). However, increased mRNA expression of TCR receptor and GATA3 genes in contrast with T-bet factor indicates increased $\mathrm{T}$ lymphocytes infiltration in the placenta of GDM patients, which have rather Th2 than Th1 phenotype (Mrizak et al. 2014). In the context of cell activation, GDM patients treated by both diet only or by insulin have increased percentage of activated Th (CD4+CD25+) cells, memory $\mathrm{T}(\mathrm{CD} 4+\mathrm{CD} 45 \mathrm{RO}+)$ cells and decreased naïve $\mathrm{T}(\mathrm{CD} 4+\mathrm{CD} 45 \mathrm{RA}+)$ cells in peripheral blood compared to healthy pregnant women suggesting higher immune activity in GDM compared to physiological pregnancy (Mahmoud et al. 2005). Accordingly, increased percentage of costimulatory molecules CD4+ Th and CD8+ Tc cells expressing early activation marker CD69 were described in GDM patients (Pendeloski et al. 2015). Importantly, GDM was associated with an elevation of the whole lymphocyte population and with a change of activation status of Th (CD4) and Tc (CD8) lymphocyte proportion (Lapolla et al. 2005). By contrast, GDM was not related to alterations in the percentage of antiinflammatory CD4+CD127low+/-CD25+FoxP3+ Treg cells within the total CD4+ $\mathrm{T}$ cell pool (Schober et al. 2014). Moreover, the proinflammatory IL-17 cytokine link to Th17 lymphocyte response could have potential deleterious effects. Increased IL-17 levels were found in preeclampsia or other pregnancy-related complications (Fu et al. 2014). However, maternal Th17 lymphocyte number is unchanged during pregnancy (Nakashima et al. 2010), preeclampsia, GDM or chronic diabetes and so innate lymphoid cells were established as a potential source of IL-17, because of cytokine production shared with Th lymphocytes (Barnie et al. 2015). Furthermore, cell subpopulations belonging to NK cell population in maternal peripheral blood and placenta are altered in GDM women (Chiba et al. 2016, Hara Cde et al. 2016). These immune cells are characterized by increased TNF- $\alpha$ and INF- $\gamma$ production supporting inflammatory reactions in women with GDM (Chiba et al. 2016).

Adipose tissue homeostasis during pregnancy and GDM could also be influenced by endoplasmic reticulum (ER) stress leading to inflammation and increased IL-1 $\beta$ production. ER stress markers were increased in adipose tissue of obese compared to lean pregnant women and higher in adipose tissue of women with GDM compared to BMI-matched normal glucose-tolerant women suggesting a possible contribution of ER stress in the etiopathogenesis of GDM (Liong \& Lappas 2015). Interestingly, ER stress in human placenta is triggered by labor and could contribute to the pathophysiology of preeclampsia ( $\mathrm{Fu}$ et al. 2015, Veerbeek et al. 2015, Yung et al. 2015). Similarly, mitochondrial damage and decreased mitochondrial respiration in trophoblast cells together with the abnormal metabolic flexibility of these cells are associated with GDM and maternal obesity (Mele et al. 2014, Muralimanoharan et al. 2016). Besides ER stress, mitochondrial damage, insufficient function and changed expression profile of enlarged adipose tissue, obesity is associated with increased levels of free fatty acids (FFAs) with deleterious effects on skeletal muscle, liver and endothelial cells mediated by enhanced insulin resistance (Boden 2008). Similar to obesity and T2DM, GDM is associated with increased FFA levels (Meyer et al. 1996, Bomba-Opon 2006), while newborns of GDM women have normal levels possibly due to the lipogenic and antilipolytic activity of the fetus (Bomba-Opon 2006, Jovandaric \& Ivanovski 2017). Increased FFA accompanying obesity represents one of the factors potentially responsible for decreased insulin sensitivity and GDM development in pregnancy. In summary, adipose tissue is an active endocrine organ secreting factors with the ability to markedly alter insulin sensitivity. Its dysfunction characterized by changes in expression of numerous adipokines along with adipose tissue inflammation and alterations in adipose tissue immunocompetent cells content and phenotype contributes to development of insulin resistance. These changes were described in both obesity and T2DM and to some extent, similar changes were also observed in GDM. Collectively, these findings suggest an analogous adipose tissue involvement in the pathophysiology of GDM. Further research is needed to elucidate the exact role of adipose tissue dysfunction in the development of GDM 
and to pave the way toward interventions targeting the adipose tissue to prevent and/or treat gestational diabetes.

\section{Declaration of interest}

The authors certify that they have no affiliations with, or involvement in, any organization or entity with any financial or non-financial interest in the subject matter discussed in this review.

\section{Funding}

This work and the original authors' works cited in this review were supported by AZV 15-27630A, RVO-VFN64165 and IN 00023001.

\section{Author contribution statement}

$P$ S and $A C$ wrote the manuscript. $K A$ performed a database search for relevant articles under the supervision of $A P$ and $M K . M M$ and $M$ $\mathrm{H}$ supervised the manuscript preparation. All authors discussed and commented on the manuscript prior submission.

\section{References}

Ajuwon KM \& Spurlock ME 2005 Adiponectin inhibits LPS-induced NF-kappaB activation and IL-6 production and increases PPARgamma2 expression in adipocytes. American Journal of Physiology: Regulatory, Integrative and Comparative Physiology 288 R1220-R1225. (https://doi.org/10.1152/ajpregu.00397.2004)

Al-Badri MR, Zantout MS \& Azar ST 2015 The role of adipokines in gestational diabetes mellitus. Therapeutic Advances in Endocrinology and Metabolism 6 103-108. (https://doi.org/10.1177/2042018815577039)

Alfadda AA, Sallam RM, Chishti MA, Moustafa AS, Fatma S, Alomaim WS, Al-Naami MY, Bassas AF, Chrousos GP \& Jo H 2012 Differential patterns of serum concentration and adipose tissue expression of chemerin in obesity: adipose depot specificity and gender dimorphism. Molecules and Cells 33 591-596. (https://doi. org/10.1007/s10059-012-0012-7)

Allard C, Desgagne V, Patenaude J, Lacroix M, Guillemette L, Battista MC, Doyon M, Menard J, Ardilouze JL, Perron P, et al. 2015 Mendelian randomization supports causality between maternal hyperglycemia and epigenetic regulation of leptin gene in newborns. Epigenetics $\mathbf{1 0}$ 342-351. (https://doi.org/10.1080/15592294.2015.1029700)

American Diabetes Association 2017 2. Classification and diagnosis of diabetes. Diabetes Care 40 S11-S24. (https://doi.org/10.2337/ dc17-S005)

Anderlova K, Kremen J, Dolezalova R, Housova J, Haluzikova D, Kunesova M \& Haluzik M 2006 The influence of very-low-calorie-diet on serum leptin, soluble leptin receptor, adiponectin and resistin levels in obese women. Physiological Research 55 277-283.

Arora RC, Waldmann M, Hopkins DA \& Armour JA 2003 Porcine intrinsic cardiac ganglia. Anatomical Record Part A: Discoveries in Molecular, Cellular, and Evolutionary Biology 271 249-258. (https://doi. org/10.1002/ar.a.10030)

Aslani S, Hossein-nezhad A, Maghbooli Z, Mirzaei K \& Karimi F 2011 Genetic variation in macrophage migration inhibitory factor associated with gestational diabetes mellitus and metabolic syndrome. Hormone and Metabolic Research 43 557-561. (https://doi. org/10.1055/s-0031-1275706)
Aye IL, Rosario FJ, Powell TL \& Jansson T 2015 Adiponectin supplementation in pregnant mice prevents the adverse effects of maternal obesity on placental function and fetal growth. PNAS 112 12858-12863. (https://doi.org/10.1073/pnas.1515484112)

Bao W, Baecker A, Song Y, Kiely M, Liu S \& Zhang C 2015 Adipokine levels during the first or early second trimester of pregnancy and subsequent risk of gestational diabetes mellitus: a systematic review. Metabolism 64 756-764. (https://doi.org/10.1016/j. metabol.2015.01.013)

Bari MF, Weickert MO, Sivakumar K, James SG, Snead DR, Tan BK, Randeva HS, Bastie CC \& Vatish M 2014 Elevated soluble CD163 in gestational diabetes mellitus: secretion from human placenta and adipose tissue. PLOS ONE 9 e101327. (https://doi.org/10.1371/journal. pone.0101327)

Barker G, Lim R, Georgiou HM \& Lappas M 2012 Omentin-1 is decreased in maternal plasma, placenta and adipose tissue of women with preexisting obesity. PLOS ONE 7 e42943. (https://doi.org/10.1371/journal. pone.0042943)

Barnie PA, Lin X, Liu Y, Xu H \& Su Z 2015 IL-17 producing innate lymphoid cells 3 (ILC3) but not Th17 cells might be the potential danger factor for preeclampsia and other pregnancy associated diseases. International Journal of Clinical and Experimental Pathology $\mathbf{8}$ 11100-11107.

Bassols J, Serino M, Carreras-Badosa G, Burcelin R, Blasco-Baque V, Lopez-Bermejo A \& Fernandez-Real JM 2016 Gestational diabetes is associated with changes in placental microbiota and microbiome. Pediatric Research 80 777-784. (https://doi.org/10.1038/pr.2016.155)

Bellamy L, Casas JP, Hingorani AD \& Williams D 2009 Type 2 diabetes mellitus after gestational diabetes: a systematic review and metaanalysis. Lancet 373 1773-1779. (https://doi.org/10.1016/S01406736(09)60731-5)

Berggren EK, Stuebe AM \& Boggess KA 2015 Excess maternal weight gain and large for gestational age risk among women with gestational diabetes. American Journal of Perinatology 32 251-256. (https://doi. org/10.1055/s-0034-1383848)

Bluher M 2009 Adipose tissue dysfunction in obesity. Experimental and Clinical Endocrinology and Diabetes 117 241-250. (https://doi org/10.1055/s-0029-1192044)

Boden G 2008 Obesity and free fatty acids. Endocrinology and Metabolism Clinics of North America 37 635-646. (https://doi.org/10.1016/j. ecl.2008.06.007)

Bomba-Opon D, Wielgos M, Szymanska M \& Bablok L 2006 Effects of free fatty acids on the course of gestational diabetes mellitus. Neuro Endocrinology Letters 27 277-280.

Boren J, Taskinen MR, Olofsson SO \& Levin M 2013 Ectopic lipid storage and insulin resistance: a harmful relationship. Journal of Internal Medicine 274 25-40. (https://doi.org/10.1111/joim.12071)

Borg NA, Wun KS, Kjer-Nielsen L, Wilce MC, Pellicci DG, Koh R, Besra GS, Bharadwaj M, Godfrey DI, McCluskey J, et al. 2007 CD1dlipid-antigen recognition by the semi-invariant NKT T-cell receptor. Nature 448 44-49. (https://doi.org/10.1038/nature05907)

Catalano PM, Tyzbir ED, Roman NM, Amini SB \& Sims EA 1991 Longitudinal changes in insulin release and insulin resistance in nonobese pregnant women. American Journal of Obstetrics and Gynecology 165 1667-1672. (https://doi.org/10.1016/00029378(91)90012-G)

Catalano PM, Tyzbir ED, Wolfe RR, Roman NM, Amini SB \& Sims EA 1992 Longitudinal changes in basal hepatic glucose production and suppression during insulin infusion in normal pregnant women. American Journal of Obstetrics and Gynecology 167 913-919. (https:// doi.org/10.1016/S0002-9378(12)80011-1)

Cetin O, Kurdoglu Z, Kurdoglu M \& Sahin HG 2017 Chemerin level in pregnancies complicated by preeclampsia and its relation with disease severity and neonatal outcomes. Journal of Obstetrics and Gynaecology 37 195-199. (https://doi.org/10.1080/01443615.2016.1233947) (c) 2018 Society for Endocrinology Published by Bioscientifica Ltd. Printed in Great Britain 
Chaemsaithong P, Romero R, Tarca AL, Korzeniewski SJ, Schwartz AG, Miranda J, Ahmed AI, Dong Z, Hassan SS, Yeo L, et al. 2014 Maternal plasma fetuin-A concentration is lower in patients who subsequently developed preterm preeclampsia than in uncomplicated pregnancy: a longitudinal study. Journal of Maternal-Fetal and Neonatal Medicine 28 1260-1269. (https://doi.org/10.3109/14767058.2014.954242)

Challier JC, Basu S, Bintein T, Minium J, Hotmire K, Catalano PM \& Hauguel-de Mouzon S 2008 Obesity in pregnancy stimulates macrophage accumulation and inflammation in the placenta. Placenta 29 274-281. (https://doi.org/10.1016/j.placenta.2007.12.010)

Chan T-F, Chen Y-L, Lee C-H, Chou F-H, Wu L-C, Jong S-B \& Tsai EM 2006 Decreased plsma visfatin concentrations in women with gestational diabetes mellitus. Journal of the Society for Gynecologic Investigation 13 364-367. (https://doi.org/10.1016/j.jsgi.2006.04.007)

Chang YH, Chang DM, Lin KC, Shin SJ \& Lee YJ 2011 Visfatin in overweight/obesity, type 2 diabetes mellitus, insulin resistance, metabolic syndrome and cardiovascular diseases: a meta-analysis and systemic review. Diabetes/Metabolism Research and Reviews 27 515-527. (https://doi.org/10.1002/dmrr.1201)

Chatterjee P, Seal S, Mukherjee S, Kundu R, Mukherjee S, Ray S, Mukhopadhyay S, Majumdar SS \& Bhattacharya S 2013 Adipocyte fetuin-A contributes to macrophage migration into adipose tissue and polarization of macrophages. Journal of Biological Chemistry 288 28324-28330. (https://doi.org/10.1074/jbc.C113.495473)

Chatzigeorgiou A, Phieler J, Gebler J, Bornstein SR \& Chavakis T 2013 CD40L stimulates the crosstalk between adipocytes and inflammatory cells. Hormone and Metabolic Research 45 741-747. (https://doi. org/10.1055/s-0033-1348221)

Chen J, Tan B, Karteris E, Zervou S, Digby J, Hillhouse EW, Vatish M \& Randeva HS 2006 Secretion of adiponectin by human placenta: differential modulation of adiponectin and its receptors by cytokines. Diabetologia 49 1292-1302. (https://doi.org/10.1007/s00125-0060194-7)

Chen D, Fang Q, Chai Y, Wang H, Huang H \& Dong M 2007 Serum resistin in gestational diabetes mellitus and early postpartum. Clinical Endocrinology 67 208-211. (https://doi.org/10.1111/j.13652265.2007.02862.x)

Chiba H, Fukui A, Fuchinoue K, Funamizu A, Tanaka K \& Mizunuma H 2016 Expression of natural cytotoxicity receptors on and intracellular cytokine production by NK cells in women with gestational diabetes mellitus. American Journal of Reproductive Immunology 75 529-538. (https://doi.org/10.1111/aji.12491)

Chung S, Yai H, Caito S, Hwang JW, Arunachalam G \& Rahman I 2010 Regulation of SIRT1 cellular functions: role of polyphenols. Archives of Biochemistry and Biophysics 501 79-90. (https://doi.org/10.1016/j. abb.2010.05.003)

Cinkajzlova A, Mraz M \& Haluzik M 2017 Lymphocytes and macrophages in adipose tissue in obesity: markers or makers of subclinical inflammation? Protoplasma 254 1219-1232. (https://doi.org/10.1007/ s00709-017-1082-3)

Cinti S, Mitchell G, Barbatelli G, Murano I, Ceresi E, Faloia E, Wang S, Fortier M, Greenberg AS \& Obin MS 2005 Adipocyte death defines macrophage localization and function in adipose tissue of obese mice and humans. Journal of Lipid Research 46 2347-2355. (https://doi. org/10.1194/jlr.M500294-JLR200)

Clausen TD, Mathiesen ER, Hansen T, Pedersen O, Jensen DM, Lauenborg J, Schmidt L \& Damm P 2009 Overweight and the metabolic syndrome in adult offspring of women with diet-treated gestational diabetes mellitus or type 1 diabetes. Journal of Clinical Endocrinology and Metabolism 94 2464-2470. (https://doi.org/10.1210/ jc.2009-0305)

Claycombe K, King LE \& Fraker PJ 2008 A role for leptin in sustaining lymphopoiesis and myelopoiesis. PNAS 105 2017-2021. (https://doi. org/10.1073/pnas.0712053105)

Dabelea D, Mayer-Davis EJ, Lamichhane AP, D'Agostino RB Jr, Liese AD, Vehik KS, Narayan KM, Zeitler P \& Hamman RF 2008 Association of intrauterine exposure to maternal diabetes and obesity with type 2 diabetes in youth: the SEARCH Case-Control Study. Diabetes Care $\mathbf{3 1}$ 1422-1426. (https://doi.org/10.2337/dc07-2417)

de Souza Batista CM, Yang RZ, Lee MJ, Glynn NM, Yu DZ, Pray J, Ndubuizu K, Patil S, Schwartz A, Kligman M, et al. 2007 Omentin plasma levels and gene expression are decreased in obesity. Diabetes 56 1655-1661. (https://doi.org/10.2337/db06-1506)

Desai M, Beall M \& Ross MG 2013 Developmental origins of obesity: programmed adipogenesis. Current Diabetes Reports 13 27-33. (https:// doi.org/10.1007/s11892-012-0344-x)

Di Cianni G, Volpe L, Lencioni C, Miccoli R, Cuccuru I, Ghio A, Chatzianagnostou K, Bottone P, Teti G, Del Prato S, et al. 2003 Prevalence and risk factors for gestational diabetes assessed by universal screening. Diabetes Research and Clinical Practice 62 131-137. (https://doi.org/10.1016/j.diabres.2003.07.004)

Drake AJ \& Reynolds RM 2010 Impact of maternal obesity on offspring obesity and cardiometabolic disease risk. Reproduction 140 387-398. (https://doi.org/10.1530/REP-10-0077)

Dudley DJ, Chen CL, Mitchell MD, Daynes RA \& Araneo BA 1993 Adaptive immune responses during murine pregnancy: pregnancyinduced regulation of lymphokine production by activated T lymphocytes. American Journal of Obstetrics and Gynecology 168 1155-1163. (https://doi.org/10.1016/0002-9378(93)90361-L)

El-Mesallamy HO, El-Derany MO \& Hamdy NM 2011 Serum omentin-1 and chemerin levels are interrelated in patients with Type 2 diabetes mellitus with or without ischaemic heart disease. Diabetic Medicine 28 1194-1200. (https://doi.org/10.1111/j.1464-5491.2011.03353.x)

Fatima SS, Alam F, Chaudhry B \& Khan TA 2017 Elevated levels of chemerin, leptin, and interleukin-18 in gestational diabetes mellitus. Journal of Maternal-Fetal and Neonatal Medicine 30 1023-1028. (https:// doi.org/10.1080/14767058.2016.1199671)

Feng R, Li Y, Wang C, Luo C, Liu L, Chuo F, Li Q \& Sun C 2014 Higher vaspin levels in subjects with obesity and type 2 diabetes mellitus: a meta-analysis. Diabetes Research and Clinical Practice 106 88-94. (https://doi.org/10.1016/j.diabres.2014.07.026)

Fu B, Tian Z \& Wei H 2014 TH17 cells in human recurrent pregnancy loss and pre-eclampsia. Cellular and Molecular Immunology 11 564-570. (https://doi.org/10.1038/cmi.2014.54)

Fu J, Zhao L, Wang L \& Zhu X 2015 Expression of markers of endoplasmic reticulum stress-induced apoptosis in the placenta of women with early and late onset severe pre-eclampsia. Taiwanese Journal of Obstetrics and Gynecology 54 19-23. (https://doi.org/10.1016/j. tjog.2014.11.002)

Fukuhara A, Matsuda M, Nishizawa M, Segawa K, Tanaka M, Kishimoto K, Matsuki Y, Murakami M, Ichisaka T, Murakami H, et al. 2005 Visfatin: a protein secreted by visceral fat that mimics the effects of insulin. Science 307 426-430. (https://doi.org/10.1126/science.1097243)

Gaillard R, Steegers EA, Duijts L, Felix JF, Hofman A, Franco OH \& Jaddoe VW 2014 Childhood cardiometabolic outcomes of maternal obesity during pregnancy: the Generation R Study. Hypertension 63 683-691. (https://doi.org/10.1161/HYPERTENSIONAHA.113.02671)

Gao XL, Yang HX \& Zhao Y 2008 Variations of tumor necrosis factoralpha, leptin and adiponectin in mid-trimester of gestational diabetes mellitus. Chinese Medical Journal 121 701-705.

Gaudet L, Ferraro ZM, Wen SW \& Walker M 2014 Maternal obesity and occurrence of fetal macrosomia: a systematic review and metaanalysis. BioMed Research International 2014 640291. (https://doi. org/10.1155/2014/640291)

Gkiomisi A, Makedou KG, Anastasilakis AD, Polyzos SA, Kourtis A, Gerou S, Gavana E, Dagklis T, Rousso D \& Giannoulis C 2013 Serum vaspin levels in women with and without gestational diabetes mellitus during pregnancy and postpartum. Cytokine 61 127-132. (https://doi.org/10.1016/j.cyto.2012.09.006)

Goralski KB, McCarthy TC, Hanniman EA, Zabel BA, Butcher EC, Parlee SD, Muruganandan S \& Sinal CJ 2007 Chemerin, a novel adipokine that regulates adipogenesis and adipocyte metabolism. http://joe.endocrinology-journals.org

https://doi.org/10.1530/JOE-18-0032
() 2018 Society for Endocrinology Published by Bioscientifica Ltd. Printed in Great Britain 
Journal of Biological Chemistry 282 28175-28188. (https://doi. org/10.1074/jbc.M700793200)

Gruen ML, Hao M, Piston DW \& Hasty AH 2007 Leptin requires canonical migratory signaling pathways for induction of monocyte and macrophage chemotaxis. American Journal of Physiology: Cell Physiology 293 C1481-C1488. (https://doi.org/10.1152/ ajpcell.00062.2007)

Haider DG, Handisurya A, Storka A, Vojtassakova E, Luger A, Pacini G, Tura A, Wolzt M \& Kautzky-Willer A 2007 Visfatin response to glucose is reduced in women with gestational diabetes mellitus. Diabetes Care 30 1889-1891. (https://doi.org/10.2337/dc07-0013)

Halaas JL, Gajiwala KS, Maffei M, Cohen SL, Chait BT, Rabinowitz D, Lallone RL, Burley SK \& Friedman JM 1995 Weight-reducing effects of the plasma protein encoded by the obese gene. Science $\mathbf{2 6 9} 543-546$. (https://doi.org/10.1126/science.7624777)

Halberg N, Wernstedt-Asterholm I \& Scherer PE 2008 The adipocyte as an endocrine cell. Endocrinology and Metabolism Clinics of North America 37 753-768, x-xi. (https://doi.org/10.1016/i.ecl.2008.07.002)

Haluzik M 2005 Adiponectin and its potential in the treatment of obesity, diabetes and insulin resistance. Current Opinion in Investigational Drugs 6 988-993.

Haluzik M, Parizkova J \& Haluzik MM 2004 Adiponectin and its role in the obesity-induced insulin resistance and related complications. Physiological Research 53 123-129.

Handisurya A, Riedl M, Vila G, Maier C, Clodi M, Prikoszovich T, Ludvik B, Prager G, Luger A \& Kautzky-Willer A 2010 Serum vaspin concentrations in relation to insulin sensitivity following RYGBinduced weight loss. Obesity Surgery 20 198-203. (https://doi. org/10.1007/s11695-009-9882-y)

Hara C de C, Franca EL, Fagundes DL, de Queiroz AA, Rudge MV, Honorio-Franca AC \& Calderon Ide M 2016 Characterization of natural killer cells and cytokines in maternal placenta and fetus of diabetic mothers. Journal of Immunology Research 20167154524. (https://doi.org/10.1155/2016/7154524)

Hare KJ, Bonde L, Svare JA, Randeva HS, Asmar M, Larsen S, Vilsboll T \& Knop FK 2014 Decreased plasma chemerin levels in women with gestational diabetes mellitus. Diabetic Medicine 31 936-940. (https:// doi.org/10.1111/dme.12436)

Hendler I, Blackwell SC, Mehta SH, Whitty JE, Russell E, Sorokin Y \& Cotton DB 2005 The levels of leptin, adiponectin, and resistin in normal weight, overweight, and obese pregnant women with and without preeclampsia. American Journal of Obstetrics and Gynecology 193 979-983. (https://doi.org/10.1016/j.ajog.2005.06.041)

Heslehurst N, Ells LJ, Simpson H, Batterham A, Wilkinson J \& Summerbell CD 2007 Trends in maternal obesity incidence rates, demographic predictors, and health inequalities in 36,821 women over a 15-year period. British Journal of Obstetrics and Gynaecology 114 187-194. (https://doi.org/10.1111/j.1471-0528.2006.01180.x)

Hod M, Merlob P, Friedman S, Schoenfeld A \& Ovadia J 1991 Gestational diabetes mellitus. A survey of perinatal complications in the 1980s. Diabetes 40 (Supplement 2) 74-78. (https://doi.org/10.2337/ diab.40.2.S74)

Hollander MH, Paarlberg KM \& Huisjes AJ 2007 Gestational diabetes: a review of the current literature and guidelines. Obstetrical and Gynecological Survey 62 125-136. (https://doi.org/10.1097/01. ogx.0000253303.92229.59)

Hosogai N, Fukuhara A, Oshima K, Miyata Y, Tanaka S, Segawa K, Furukawa S, Tochino Y, Komuro R, Matsuda M, et al. 2007 Adipose tissue hypoxia in obesity and its impact on adipocytokine dysregulation. Diabetes 56 901-911. (https://doi.org/10.2337/db060911)

Hsu WY, Chao YW, Tsai YL, Lien CC, Chang CF, Deng MC, Ho LT, Kwok CF \& Juan CC 2011 Resistin induces monocyte-endothelial cell adhesion by increasing ICAM-1 and VCAM-1 expression in endothelial cells via p38MAPK-dependent pathway. Journal of Cellular Physiology 226 2181-2188. (https://doi.org/10.1002/jcp.22555)
Huo Y, Liu SX, Song GY, Ren LP, Wang C \& Zhang DH 2015 Plasma levels and placental expression of vaspin in pregnant women with diabetes mellitus. Brazilian Journal of Medical and Biological Research 48 273-279. (https://doi.org/10.1590/1414-431X20143432)

Iliodromiti S, Sassarini J, Kelsey TW, Lindsay RS, Sattar N \& Nelson SM 2016 Accuracy of circulating adiponectin for predicting gestational diabetes: a systematic review and meta-analysis. Diabetologia 59 692-699. (https://doi.org/10.1007/s00125-015-3855-6)

Iyidir OT, Degertekin CK, Yilmaz BA, Altinova AE, Toruner FB, Bozkurt N, Ayvaz G \& Akturk M 2015 Serum levels of fetuin A are increased in women with gestational diabetes mellitus. Archives of Gynecology and Obstetrics 291 933-937. (https://doi.org/10.1007/s00404-014-3490-3)

Jang JE, Ko MS, Yun JY, Kim MO, Kim JH, Park HS, Kim AR, Kim HJ, Kim BJ, Ahn YE, et al. 2016 Nitric oxide produced by macrophages inhibits adipocyte differentiation and promotes profibrogenic responses in preadipocytes to induce adipose tissue fibrosis. Diabetes 65 2516-2528. (https://doi.org/10.2337/db15-1624)

Jernas M, Palming J, Sjoholm K, Jennische E, Svensson PA, Gabrielsson BG, Levin M, Sjogren A, Rudemo M, Lystig TC, et al. 2006 Separation of human adipocytes by size: hypertrophic fat cells display distinct gene expression. FASEB Journal 20 1540-1542. (https://doi. org/10.1096/fj.05-5678fje)

Jia X, Wang S, Ma N, Li X, Guo L, Liu X, Dong T, Liu Y \& Lu Q 2015 Comparative analysis of vaspin in pregnant women with and without gestational diabetes mellitus and healthy non-pregnant women. Endocrine 48 533-540. (https://doi.org/10.1007/s12020-0140318-7)

Jialal I, Devaraj S, Bettaieb A, Haj F \& Adams-Huet B 2015 Increased adipose tissue secretion of Fetuin-A, lipopolysaccharide-binding protein and high-mobility group box protein 1 in metabolic syndrome. Atherosclerosis 241 130-137. (https://doi.org/10.1016/j. atherosclerosis.2015.04.814)

Jo J, Gavrilova O, Pack S, Jou W, Mullen S, Sumner AE, Cushman SW \& Periwal V 2009 Hypertrophy and/or hyperplasia: dynamics of adipose tissue growth. PLoS Computational Biology 5 e1000324. (https://doi. org/10.1371/journal.pcbi.1000324)

Joller N, Lozano E, Burkett PR, Patel B, Xiao S, Zhu C, Xia J, Tan TG, Sefik E, Yajnik V, et al. 2014 Treg cells expressing the coinhibitory molecule TIGIT selectively inhibit proinflammatory Th1 and Th17 cell responses. Immunity 40 569-581. (https://doi.org/10.1016/j. immuni.2014.02.012)

Jovandaric MZ \& Ivanovski PI 2017 Free fatty acids of newborns form women with gestational diabetes mellitus. Fetal and Pediatric Pathology 36 190-194. (https://doi.org/10.1080/15513815.2017.1281365)

Kalabay L, Cseh K, Pajor A, Baranyi E, Csakany GM, Melczer Z, Speer G, Kovacs M, Siller G, Karadi I, et al. 2002 Correlation of maternal serum fetuin/alpha2-HS-glycoprotein concentration with maternal insulin resistance and anthropometric parameters of neonates in normal pregnancy and gestational diabetes. European Journal of Endocrinology 147 243-248. (https://doi.org/10.1530/eje.0.1470243)

Kanagalingam MG, Forouhi NG, Greer IA \& Sattar N 2005 Changes in booking body mass index over a decade: retrospective analysis from a Glasgow Maternity Hospital. British Journal of Obstetrics and Gynaecology 112 1431-1433. (https://doi.org/10.1111/j.14710528.2005.00685.x)

Kang K, Reilly SM, Karabacak V, Gangl MR, Fitzgerald K, Hatano B \& Lee CH 2008 Adipocyte-derived Th2 cytokines and myeloid PPARdelta regulate macrophage polarization and insulin sensitivity. Cell Metabolism 7 485-495. (https://doi.org/10.1016/j.cmet.2008.04.002)

Kautzky-Willer A, Pacini G, Tura A, Bieglmayer C, Schneider B, Ludvik B, Prager R \& Waldhausl W 2001 Increased plasma leptin in gestational diabetes. Diabetologia 44 164-172. (https://doi.org/10.1007/ s001250051595)

Kleiblova P, Springer D \& Haluzik M 2006 The influence of hormonal changes during menstrual cycle on serum adiponectin concentrations in healthy women. Physiological Research 55 661-666.
(C) 2018 Society for Endocrinology Published by Bioscientifica Ltd. Printed in Great Britain 
Kleiblova P, Dostalova I, Bartlova M, Lacinova Z, Ticha I, Krejci V, Springer D, Kleibl Z \& Haluzik M 2010 Expression of adipokines and estrogen receptors in adipose tissue and placenta of patients with gestational diabetes mellitus. Molecular and Cellular Endocrinology $\mathbf{3 1 4}$ 150-156. (https://doi.org/10.1016/j.mce.2009.08.002)

Koenen TB, Stienstra R, van Tits LJ, Joosten LA, van Velzen JF, Hijmans A, Pol JA, van der Vliet JA, Netea MG, Tack CJ, et al. 2011 The inflammasome and caspase- 1 activation: a new mechanism underlying increased inflammatory activity in human visceral adipose tissue. Endocrinology 152 3769-3778. (https://doi.org/10.1210/ en.2010-1480)

Kralisch S, Hoffmann A, Lossner U, Kratzsch J, Bluher M, Stumvoll M, Fasshauer M \& Ebert T 2017 Regulation of the novel adipokines/ hepatokines fetuin A and fetuin B in gestational diabetes mellitus. Metabolism 68 88-94. (https://doi.org/10.1016/j.metabol.2016.11.017)

Krizova J, Eretova V, Haluzikova D, Anderlova K, Housova J, Kotrlikova E \& Haluzik M 2004 Soluble leptin receptor and leptin levels in pregnant women before and after delivery. Endocrine Research 30 379-385. (https://doi.org/10.1081/ERC-200034301)

Krzyzanowska K, Krugluger W, Mittermayer F, Rahman R, Haider D, Shnawa N \& Schernthaner G 2006 Increased visfatin concentrations in women with gestational diabetes mellitus. Clinical Science $\mathbf{1 1 0}$ 605-609. (https://doi.org/10.1042/CS20050363)

Kuzmicki M, Telejko B, Szamatowicz J, Zonenberg A, Nikolajuk A, Kretowski A \& Gorska M 2009 High resistin and interleukin-6 levels are associated with gestational diabetes mellitus. Gynecological Endocrinology 25 258-263. (https://doi. org/10.1080/09513590802653825)

Lapolla A, Dalfra MG, Sanzari M, Fedele D, Betterle C, Masin M, Zanchetta R, Faggian D, Masotti M, Nucera V, et al. 2005 Lymphocyte subsets and cytokines in women with gestational diabetes mellitus and their newborn. Cytokine 31 280-287. (https://doi.org/10.1016/j. cyto.2005.05.004)

Lappas M, Yee K, Permezel M \& Rice GE 2005 Release and regulation of leptin, resistin and adiponectin from human placenta, fetal membranes, and maternal adipose tissue and skeletal muscle from normal and gestational diabetes mellitus-complicated pregnancies. Journal of Endocrinology 186 457-465. (https://doi.org/10.1677/ joe.1.06227)

Lavie CJ, Milani RV \& Ventura HO 2009 Obesity and cardiovascular disease: risk factor, paradox, and impact of weight loss. Journal of the American College of Cardiology 53 1925-1932. (https://doi. org/10.1016/j.jacc.2008.12.068)

Leddy MA, Power ML \& Schulkin J 2008 The impact of maternal obesity on maternal and fetal health. Reviews in Obstetrics and Gynecology $\mathbf{1}$ 170-178.

Lee BC, Kim MS, Pae M, Yamamoto Y, Eberle D, Shimada T, Kamei N, Park HS, Sasorith S, Woo JR, et al. 2016 Adipose natural killer cells regulate adipose tissue macrophages to promote insulin resistance in obesity. Cell Metabolism 23 685-698. (https://doi.org/10.1016/j. cmet.2016.03.002)

Lekva T, Michelsen AE, Aukrust P, Henriksen T, Bollerslev J \& Ueland T 2017 Leptin and adiponectin as predictors of cardiovascular risk after gestational diabetes mellitus. Cardiovascular Diabetology 16 5. (https:// doi.org/10.1186/s12933-016-0492-4)

Lewandowski KC, Stojanovic N, Press M, Tuck SM, Szosland K, Bienkiewicz M, Vatish M, Lewinski A, Prelevic GM \& Randeva HS 2007 Elevated serum levels of visfatin in gestational diabetes: a comparative study across various degrees of glucose tolerance. Diabetologia 50 1033-1037. (https://doi.org/10.1007/s00125-0070610-7)

Li N, Liu E, Guo J, Pan L, Li B, Wang P, Liu J, Wang Y, Liu G, Baccarelli AA, et al. 2013 Maternal prepregnancy body mass index and gestational weight gain on pregnancy outcomes. PLOS ONE $\mathbf{8}$ e82310. (https://doi.org/10.1371/journal.pone.0082310)
Li XM, Ji H, Li CJ, Wang PH, Yu P \& Yu DM 2015 Chemerin expression in Chinese pregnant women with and without gestational diabetes mellitus. Annals of Endocrinology 76 19-24. (https://doi.org/10.1016/j. ando.2014.10.001)

Liong S \& Lappas M 2015 Endoplasmic reticulum stress is increased in adipose tissue of women with gestational diabetes. PLOS ONE $\mathbf{1 0}$ e0122633. (https://doi.org/10.1371/journal.pone.0122633)

Liu L, Hong Z \& Zhang L 2015 Associations of prepregnancy body mass index and gestational weight gain with pregnancy outcomes in nulliparous women delivering single live babies. Scientific Reports 5 12863. (https://doi.org/10.1038/srep12863)

Lopez-Tinoco C, Roca M, Fernandez-Deudero A, Garcia-Valero A, Bugatto F, Aguilar-Diosdado M \& Bartha JL 2012 Cytokine profile, metabolic syndrome and cardiovascular disease risk in women with late-onset gestational diabetes mellitus. Cytokine 58 14-19. (https:// doi.org/10.1016/j.cyto.2011.12.004)

Lord GM, Matarese G, Howard JK, Baker RJ, Bloom SR \& Lechler RI 1998 Leptin modulates the T-cell immune response and reverses starvationinduced immunosuppression. Nature 394 897-901. (https://doi. org/10.1038/29795)

Madhumitha H, Mohan V, Deepa M, Babu S \& Aravindhan V 2014 Increased Th1 and suppressed Th2 serum cytokine levels in subjects with diabetic coronary artery disease. Cardiovascular Diabetology 131. (https://doi.org/10.1186/1475-2840-13-1)

Mahmoud F, Abul H, Omu A \& Haines D 2005 Lymphocyte sub-populations in gestational diabetes. American Journal of Reproductive Immunology 53 21-29. (https://doi.org/10.1111/j.16000897.2004.00241.x)

Manduteanu I, Pirvulescu M, Gan AM, Stan D, Simion V, Dragomir E, Calin M, Manea A \& Simionescu M 2010 Similar effects of resistin and high glucose on P-selectin and fractalkine expression and monocyte adhesion in human endothelial cells. Biochemical and Biophysical Research Communications 391 1443-1448. (https://doi.org/10.1016/j. bbrc.2009.12.089)

Mantovani A, Sica A, Sozzani S, Allavena P, Vecchi A \& Locati M 2004 The chemokine system in diverse forms of macrophage activation and polarization. Trends in Immunology 25 677-686. (https://doi. org/10.1016/j.it.2004.09.015)

McDonnell ME, Ganley-Leal LM, Mehta A, Bigornia SJ, Mott M, Rehman Q, Farb MG, Hess DT, Joseph L, Gokce N, et al. 2012 B lymphocytes in human subcutaneous adipose crown-like structures. Obesity 20 1372-1378. (https://doi.org/10.1038/oby.2012.54)

Meex RC, Hoy AJ, Morris A, Brown RD, Lo JC, Burke M, Goode RJ, Kingwell BA, Kraakman MJ, Febbraio MA, et al. 2015 Fetuin $\mathrm{B}$ is a secreted hepatocyte factor linking steatosis to impaired glucose metabolism. Cell Metabolism 22 1078-1089. (https://doi. org/10.1016/j.cmet.2015.09.023)

Megia A, Vendrell J, Gutierrez C, Sabate M, Broch M, FernandezReal JM \& Simon I 2008 Insulin sensitivity and resistin levels in gestational diabetes mellitus and after parturition. European Journal of Endocrinology 158 173-178. (https://doi.org/10.1530/EJE-07-0671)

Mele J, Muralimanoharan S, Maloyan A \& Myatt L 2014 Impaired mitochondrial function in human placenta with increased maternal adiposity. American Journal of Physiology: Endocrinology and Metabolism 307 E419-E425. (https://doi.org/10.1152/ ajpendo.00025.2014)

Metzger BE, Lowe LP, Dyer AR, Trimble ER, Chaovarindr U, Coustan DR, Hadden DR, McCance DR, Hod M, McIntyre HD, et al. 2008 Hyperglycemia and adverse pregnancy outcomes. New England Journal of Medicine 358 1991-2002. (https://doi.org/10.1056/ NEJMoa0707943)

Meyer B, Calvert D \& Moses R 1996 Free fatty acids and gestational diabetes mellitus. Australian and New Zealand Journal of Obstetrics and Gynaecology 36 255-257. (https://doi.org/10.1111/j.1479-828X.1996. tb02705.x)
(C) 2018 Society for Endocrinology Published by Bioscientifica Ltd. Printed in Great Britain 
Mills CD, Kincaid K, Alt JM, Heilman MJ \& Hill AM 2000 M-1/M-2 macrophages and the Th1/Th2 paradigm. Journal of Immunology 164 6166-6173. (https://doi.org/10.4049/jimmunol.164.12.6166)

Mm WQ, Fan J, Khor S, Song M, Hong W \& Dai X 2014 Serum vaspin levels and vaspin mRNA expression in subcutaneous adipose tissue in women with gestational diabetes mellitus. European Journal of Obstetrics and Gynecology and Reproductive Biology 182 98-101. (https:// doi.org/10.1016/j.ejogrb.2014.09.008)

Morris DL, Oatmen KE, Mergian TA, Cho KW, DelProposto JL, Singer K, Evans-Molina C, O'Rourke RW \& Lumeng CN 2016 CD40 promotes MHC class II expression on adipose tissue macrophages and regulates adipose tissue CD4+ T cells with obesity. Journal of Leukocyte Biology 99 1107-1119. (https://doi.org/10.1189/jlb.3A0115-009R)

Moschen AR, Kaser A, Enrich B, Mosheimer B, Theurl M, Niederegger H \& Tilg H 2007 Visfatin, an adipocytokine with proinflammatory and immunomodulating properties. Journal of Immunology $\mathbf{1 7 8}$ 1748-1758. (https://doi.org/10.4049/jimmunol.178.3.1748)

Mraz M \& Haluzik M 2014 The role of adipose tissue immune cells in obesity and low-grade inflammation. Journal of Endocrinology 222 R113-R127. (https://doi.org/10.1530/JOE-14-0283)

Mrizak I, Grissa O, Henault B, Fekih M, Bouslema A, Boumaiza I, Zaouali M, Tabka Z \& Khan NA 2014 Placental infiltration of inflammatory markers in gestational diabetic women. General Physiology and Biophysics 33 169-176. (https://doi.org/10.4149/ gpb_2013075)

Mumtaz S, AlSaif S, Wray S \& Noble K 2015 Inhibitory effect of visfatin and leptin on human and rat myometrial contractility. Life Science 125 57-62. (https://doi.org/10.1016/j.lfs.2015.01.020)

Muralimanoharan S, Maloyan A \& Myatt L 2016 Mitochondrial function and glucose metabolism in the placenta with gestational diabetes mellitus: role of miR-143. Clinical Science 130 931-941. (https://doi. org/10.1042/CS20160076)

Nahum Sacks K, Friger M, Shoham-Vardi I, Abokaf H, Spiegel E, Sergienko R, Landau D \& Sheiner E 2016 Prenatal exposure to gestational diabetes mellitus as an independent risk factor for longterm neuropsychiatric morbidity of the offspring. American Journal of Obstetrics and Gynecology 215 380.e381-380.e387. (https://doi. org/10.1016/j.ajog.2016.03.030)

Nakashima A, Ito M, Yoneda S, Shiozaki A, Hidaka T \& Saito S 2010 Circulating and decidual Th17 cell levels in healthy pregnancy. American Journal of Reproductive Immunology 63 104-109. (https://doi. org/10.1111/j.1600-0897.2009.00771.x)

Ng PC, Lee CH, Lam CW, Wong E, Chan IH \& Fok TF 2004 Plasma ghrelin and resistin concentrations are suppressed in infants of insulin-dependent diabetic mothers. Journal of Clinical Endocrinology and Metabolism 89 5563-5568. (https://doi.org/10.1210/jc.2004-0736)

Nishihira J 2000 Macrophage migration inhibitory factor (MIF): its essential role in the immune system and cell growth. Journal of Interferon and Cytokine Research 20 751-762. (https://doi. org/10.1089/10799900050151012)

Nishimura S, Manabe I, Nagasaki M, Eto K, Yamashita H, Ohsugi M, Otsu M, Hara K, Ueki K, Sugiura S, et al. 2009 CD8+ effector T cells contribute to macrophage recruitment and adipose tissue inflammation in obesity. Nature Medicine 15 914-920. (https://doi. org/10.1038/nm.1964)

Ogden CL, Carroll MD, Fryar CD, Flegal KM 2015 Prevalence of obesity among adults and youth: United States, 2011-2014. National Center for Health Statistics Data Brief 1-8.

Ouchi N, Kihara S, Arita Y, Maeda K, Kuriyama H, Okamoto Y, Hotta K, Nishida M, Takahashi M, Nakamura T, et al. 1999 Novel modulator for endothelial adhesion molecules: adipocyte-derived plasma protein adiponectin. Circulation 100 2473-2476. (https://doi.org/10.1161/01. CIR.100.25.2473)

Papathanassoglou E, El-Haschimi K, Li XC, Matarese G, Strom T \& Mantzoros C 2006 Leptin receptor expression and signaling in lymphocytes: kinetics during lymphocyte activation, role in lymphocyte survival, and response to high fat diet in mice. Journal of Immunology 176 7745-7752. (https://doi.org/10.4049/ jimmunol.176.12.7745)

Pendeloski KP, Mattar R, Torloni MR, Gomes CP, Alexandre SM \& Daher S 2015 Immunoregulatory molecules in patients with gestational diabetes mellitus. Endocrine 50 99-109. (https://doi.org/10.1007/ s12020-015-0567-0)

Pfau D, Stepan H, Kratzsch J, Verlohren M, Verlohren HJ, Drynda K, Lossner U, Bluher M, Stumvoll M \& Fasshauer M 2010 Circulating levels of the adipokine chemerin in gestational diabetes mellitus. Hormone Research in Paediatrics 74 56-61. (https://doi. org/10.1159/000282114)

Piestrzeniewicz K, Luczak K, Komorowski J, Maciejewski M, Jankiewicz Wika J \& Goch JH 2008 Resistin increases with obesity and atherosclerotic risk factors in patients with myocardial infarction. Metabolism 57 488-493. (https://doi.org/10.1016/j. metabol.2007.11.009)

Pi-Sunyer X 2009 The medical risks of obesity. Postgraduate Medical 121 21-33. (https://doi.org/10.3810/pgm.2009.11.2074)

Pustovrh C, Jawerbaum A, Sinner D, Pesaresi M, Baier M, Micone P, Gimeno M \& Gonzalez ET 2000 Membrane-type matrix metalloproteinase-9 activity in placental tissue from patients with pre-existing and gestational diabetes mellitus. Reproduction, Fertility, and Development 12 269-275. (https://doi.org/10.1071/RD00078)

Qiu C, Williams MA, Vadachkoria S, Frederick IO \& Luthy DA 2004 Increased maternal plasma leptin in early pregnancy and risk of gestational diabetes mellitus. Obstetrics and Gynecology 103 519-525. (https://doi.org/10.1097/01.AOG.0000113621.53602.7a)

Ranheim T, Haugen F, Staff AC, Braekke K, Harsem NK \& Drevon CA 2004 Adiponectin is reduced in gestational diabetes mellitus in normal weight women. Acta Obstetricia et Gynecologica Scandinavica 83 341-347. (https://doi.org/10.1111/j.00016349.2004.00413.x)

Rinehart BK, Terrone DA, Lagoo-Deenadayalan S, Barber WH, Hale EA Martin JN Jr \& Bennett WA 1999 Expression of the placental cytokines tumor necrosis factor alpha, interleukin 1beta, and interleukin 10 is increased in preeclampsia. American Journal of Obstetrics and Gynecology 181 915-920. (https://doi.org/10.1016/ S0002-9378(99)70325-X)

Samsell L, Regier M, Walton C \& Cottrell L 2014 Importance of android/ gynoid fat ratio in predicting metabolic and cardiovascular disease risk in normal weight as well as overweight and obese children. Journal of Obesity 2014846578.

Schipper HS, Rakhshandehroo M, van de Graaf SF, Venken K, Koppen A, Stienstra R, Prop S, Meerding J, Hamers N, Besra G, et al. 2012 Natural killer $\mathrm{T}$ cells in adipose tissue prevent insulin resistance. Journal of Clinical Investigation 122 3343-3354. (https://doi.org/10.1172/ JCI62739)

Schober L, Radnai D, Spratte J, Kisielewicz A, Schmitt E, Mahnke K, Fluhr H, Uhlmann L, Sohn C \& Steinborn A 2014 The role of regulatory $\mathrm{T}$ cell (Treg) subsets in gestational diabetes mellitus. Clinical and Experimental Immunology 177 76-85. (https://doi. org/10.1111/cei.12300)

Sell H, Laurencikiene J, Taube A, Eckardt K, Cramer A, Horrighs A, Arner P \& Eckel J 2009 Chemerin is a novel adipocyte-derived factor inducing insulin resistance in primary human skeletal muscle cells. Diabetes $\mathbf{5 8}$ 2731-2740. (https://doi.org/10.2337/db09-0277)

Shoba B, Lwin ZM, Ling LS, Bay BH, Yip GW \& Kumar SD 2009 Functions of sirtuins in biological tissues. Anatomical Record 292 536-543. (https://doi.org/10.1002/ar.20875)

Sica A \& Mantovani A 2012 Macrophage plasticity and polarization: in vivo veritas. Journal of Clinical Investigation 122 787-795. (https://doi. org/10.1172/JCI59643)

Silswal N, Singh AK, Aruna B, Mukhopadhyay S, Ghosh S \& Ehtesham NZ 2005 Human resistin stimulates the pro-inflammatory cytokines TNFalpha and IL-12 in macrophages by NF-kappaB-dependent pathway. 
Biochemical and Biophysical Research Communications 334 1092-1101. (https://doi.org/10.1016/j.bbrc.2005.06.202)

Sommer C, Jenum AK, Waage CW, Morkrid K, Sletner L \& Birkeland KI 2015 Ethnic differences in BMI, subcutaneous fat, and serum leptin levels during and after pregnancy and risk of gestational diabetes. European Journal of Endocrinology 172 649-656. (https://doi. org/10.1530/EJE-15-0060)

Stefan N, Hennige AM, Staiger H, Machann J, Schick F, Krober SM, Machicao F, Fritsche A \& Haring HU 2006 Alpha2-Heremans-Schmid glycoprotein/fetuin-A is associated with insulin resistance and fat accumulation in the liver in humans. Diabetes Care 29 853-857. (https://doi.org/10.2337/diacare.29.04.06.dc05-1938)

Stepan H, Kralisch S, Klostermann K, Schrey S, Reisenbuchler C, Verlohren M, Verlohren HJ, Drynda K, Bluher M, Stumvoll M, et al. 2010 Preliminary report: circulating levels of the adipokine vaspin in gestational diabetes mellitus and preeclampsia. Metabolism 59 1054-1056. (https://doi.org/10.1016/j.metabol.2009.11.001)

Steppan CM, Bailey ST, Bhat S, Brown EJ, Banerjee RR, Wright CM, Patel HR, Ahima RS \& Lazar MA 2001 The hormone resistin links obesity to diabetes. Nature 409 307-312. (https://doi. org/10.1038/35053000)

Stothard KJ, Tennant PW, Bell R \& Rankin J 2009 Maternal overweight and obesity and the risk of congenital anomalies: a systematic review and meta-analysis. JAMA 301 636-650. (https://doi.org/10.1001/ jama.2009.113)

Sullivan SD, Umans JG \& Ratner R 2012 Gestational diabetes: implications for cardiovascular health. Current Diabetes Reports 12 43-52. (https://doi.org/10.1007/s11892-011-0238-3)

Sun K, Kusminski CM \& Scherer PE 2011 Adipose tissue remodeling and obesity. Journal of Clinical Investigation 121 2094-2101. (https://doi. org/10.1172/JCI45887)

Svoboda P, Krizova E, Cenkova K, Vapenkova K, Zidkova J, Zidek V \& Skop V 2017 Visfatin is actively secreted in vitro from U-937 macrophages, but only passively released from 3T3-L1 adipocytes and HepG2 hepatocytes. Physiological Research 66 709-714. (https://doi.org/10.1002/path.4394)

Sylven C 1993 Mechanisms of pain in angina pectoris--a critical review of the adenosine hypothesis. Cardiovascular Drugs and Therapy 7 745-759. (https://doi.org/10.1007/BF00878926)

Telejko B, Kuzmicki M, Zonenberg A, Szamatowicz J, WawrusiewiczKurylonek N, Nikolajuk A, Kretowski A \& Gorska M 2009 Visfatin in gestational diabetes: serum level and mRNA expression in fat and placental tissue. Diabetes Research and Clinical Practice 84 68-75. (https://doi.org/10.1016/j.diabres.2008.12.017)

Tenenbaum-Gavish K \& Hod M 2013 Impact of maternal obesity on fetal health. Fetal Diagnosis and Therapy 34 1-7. (https://doi. org/10.1159/000350170)

Troseid M, Nestvold TK, Rudi K, Thoresen H, Nielsen EW \& Lappegard KT 2013 Plasma lipopolysaccharide is closely associated with glycemic control and abdominal obesity: evidence from bariatric surgery. Diabetes Care 36 3627-3632. (https://doi.org/10.2337/dc13-0451)

Tsai PJ, Davis J \& Bryant-Greenwood G 2015a Systemic and placental leptin and its receptors in pregnancies associated with obesity. Reproductive Sciences 22 189-197. (https://doi. org/10.1177/1933719114537718)

Tsai PJ, Davis J, Thompson K \& Bryant-Greenwood G 2015b Visfatin/ Nampt and SIRT1: roles in postterm delivery in pregnancies associated with obesity. Reproductive Sciences 22 1028-1036. (https:// doi.org/10.1177/1933719115570908)

Unger RH 2003 Minireview: weapons of lean body mass destruction: the role of ectopic lipids in the metabolic syndrome. Endocrinology 144 5159-5165. (https://doi.org/10.1210/en.2003-0870)

van Poppel MN, Zeck W, Ulrich D, Schest EC, Hirschmugl B, Lang U, Wadsack C \& Desoye G 2014 Cord blood chemerin: differential effects of gestational diabetes mellitus and maternal obesity. Clinical Endocrinology 80 65-72. (https://doi.org/10.1111/cen.12140)
Veerbeek JH, Tissot Van Patot MC, Burton GJ \& Yung HW 2015 Endoplasmic reticulum stress is induced in the human placenta during labour. Placenta 36 88-92. (https://doi.org/10.1016/j. placenta.2014.11.005)

Veilleux A, Caron-Jobin M, Noel S, Laberge PY \& Tchernof A 2011 Visceral adipocyte hypertrophy is associated with dyslipidemia independent of body composition and fat distribution in women. Diabetes 60 1504-1511. (https://doi.org/10.2337/db10-1039)

Vozarova de Courten B, Degawa-Yamauchi M, Considine RV \& Tataranni PA 2004 High serum resistin is associated with an increase in adiposity but not a worsening of insulin resistance in Pima Indians. Diabetes 53 1279-1284. (https://doi.org/10.2337/diabetes.53.5.1279)

Wang L, Yang T, Ding Y, Zhong Y, Yu L \& Peng M 2015 Chemerin plays a protective role by regulating human umbilical vein endothelial cellinduced nitric oxide signaling in preeclampsia. Endocrine 48 299-308. (https://doi.org/10.1007/s12020-014-0286-y)

Ward MR, Jeremias A, Hibi K, Herity NA, Lo ST, Filardo SD, Lee DP, Fitzgerald PJ \& Yeung AC 2001 The influence of plaque orientation (pericardial or myocardial) on coronary arterial remodeling. Atherosclerosis 154 179-183. (https://doi.org/10.1016/S00219150(00)00459-7)

Wegmann TG, Lin H, Guilbert L \& Mosmann TR 1993 Bidirectional cytokine interactions in the maternal-fetal relationship: is successful pregnancy a TH2 phenomenon? Immunology Today 14 353-356. (https://doi.org/10.1016/0167-5699(93)90235-D)

Wensveen FM, Jelencic V, Valentic S, Sestan M, Wensveen TT, Theurich S, Glasner A, Mendrila D, Stimac D, Wunderlich FT, et al. 2015 NK cells link obesity-induced adipose stress to inflammation and insulin resistance. Nature Immunology 16 376-385. (https://doi.org/10.1038/ ni.3120)

Whitaker RC 2004 Predicting preschooler obesity at birth: the role of maternal obesity in early pregnancy. Pediatrics 114 e29-e36. (https:// doi.org/10.1542/peds.114.1.e29)

Winkler G, Kiss S, Keszthelyi L, Sapi Z, Ory I, Salamon F, Kovacs M, Vargha P, Szekeres O, Speer G, et al. 2003 Expression of tumor necrosis factor (TNF)-alpha protein in the subcutaneous and visceral adipose tissue in correlation with adipocyte cell volume, serum TNFalpha, soluble serum TNF-receptor-2 concentrations and C-peptide level. European Journal of Endocrinology 149 129-135. (https://doi. org/10.1530/eje.0.1490129)

Winzer C, Wagner O, Festa A, Schneider B, Roden M, Bancher-Todesca D, Pacini G, Funahashi T \& Kautzky-Willer A 2004 Plasma adiponectin, insulin sensitivity, and subclinical inflammation in women with prior gestational diabetes mellitus. Diabetes Care 27 1721-1727. (https:// doi.org/10.2337/diacare.27.7.1721)

Wolf AM, Wolf D, Rumpold H, Enrich B \& Tilg H 2004 Adiponectin induces the anti-inflammatory cytokines IL-10 and IL-1RA in human leukocytes. Biochemical and Biophysical Research Communications 323 630-635. (https://doi.org/10.1016/j.bbrc.2004.08.145)

Wu CS, Nohr EA, Bech BH, Vestergaard M \& Olsen J 2012 Long-term health outcomes in children born to mothers with diabetes: a population-based cohort study. PLoS ONE 7 e36727. (https://doi. org/10.1371/journal.pone.0036727)

Xiong C, Zhou A, Cao Z, Zhang Y, Qiu L, Yao C, Wang Y \& Zhang B 2016 Association of pre-pregnancy body mass index, gestational weight gain with cesarean section in term deliveries of China. Scientific Reports 6 37168. (https://doi.org/10.1038/srep37168)

Xu W, Yu L, Zhou W \& Luo M 2006 Resistin increases lipid accumulation and CD36 expression in human macrophages. Biochemical and Biophysical Research Communications 351 376-382. (https://doi. org/10.1016/j.bbrc.2006.10.051)

Yang M, Yang G, Dong J, Liu Y, Zong H, Liu H, Boden G \& Li L 2010 Elevated plasma levels of chemerin in newly diagnosed type 2 diabetes mellitus with hypertension. Journal of Investigative Medicine 58 883-886. (https://doi.org/10.2310/JIM.0b013e3181ec5db2)
() 2018 Society for Endocrinology Published by Bioscientifica Ltd. Printed in Great Britain 
Yilmaz O, Kucuk M, Kebapcilar L, Altindag T, Yuksel A, Yuvanc HO, Dal T \& Savran Y 2012 Macrophage migration-inhibitory factor is elevated in pregnant women with gestational diabetes mellitus. Gynecological Endocrinology 28 76-79. (https://doi.org/10.3109/09513590.2011.58 8757)

Young OM, Tang Z, Niven-Fairchild T, Tadesse S, Krikun G, Norwitz ER, Mor G, Abrahams VM \& Guller S 2015 Toll-like receptor-mediated responses by placental Hofbauer cells (HBCs): a potential proinflammatory role for fetal M2 macrophages. American Journal of Reproductive Immunology 73 22-35. (https://doi.org/10.1111/aji.12336)

Yu J, Zhou Y, Gui J, Li AZ, Su XL \& Feng L 2013 Assessment of the number and function of macrophages in the placenta of gestational diabetes mellitus patients. Journal of Huazhong University of Science and Technology Medical Sciences 33 725-729. (https://doi.org/10.1007/ s11596-013-1187-7)
Yung HW, Atkinson D, Campion-Smith T, Olovsson M, CharnockJones DS \& Burton GJ 2015 Differential activation of placental unfolded protein response pathways implies heterogeneity in causation of early- and late-onset pre-eclampsia. Journal of Pathology 234 262-276.

Zampieri TT, Ramos-Lobo AM, Furigo IC, Pedroso JA, Buonfiglio DC \& Donato J Jr 2015 SOCS3 deficiency in leptin receptor-expressing cells mitigates the development of pregnancy-induced metabolic changes. Molecular Metabolism 4 237-245. (https://doi.org/10.1016/j. molmet.2014.12.005)

Zeyda M, Farmer D, Todoric J, Aszmann O, Speiser M, Gyori G, Zlabinger GJ \& Stulnig TM 2007 Human adipose tissue macrophages are of an anti-inflammatory phenotype but capable of excessive proinflammatory mediator production. International Journal of Obesity $\mathbf{3 1}$ 1420-1428. (https://doi.org/10.1038/sj.ijo.0803632)

Received in final form 27 April 2018

Accepted 8 May 2018

Accepted Preprint published online 9 May 2018 